\title{
Sistem Manajemen Parkir Mobil On Street dan Off Street Berbasis Location Based Service (LBS) dan Google Maps API
}

\author{
Cornelius Venti ${ }^{\# 1}$, Yus Sholva $a^{\# 2}$, Rudy Dwi Nyoto ${ }^{\# 3}$ \\ \#Program Studi Informatika Fakultas Teknik Universitas Tanjungpura \\ Jl. Profesor Dokter H. Hadari Nawawi, Bansir Laut, Pontianak Tenggara, Kota Pontianak, Kalimantan Barat 78115

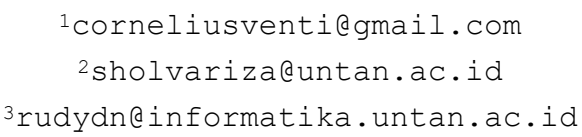

\begin{abstract}
Abstrak - Bertambahnya jumlah kendaraan sering tidak diikuti dengan bertambahnya tempat parkir. Kondisi sangat menyulitkan pengendara untuk memarkir kendaraannya karena penuh. Sehingga informasi ketersediaan lahan parkir menjadi sangat penting khususnya parkir mobil karena memerlukan tempat parkir. Pengendara tidak mengetahui ketersediaan tempat parkir yang berada di sekitar destinasi dan membuat pengendara harus mencarinya setelah sampai destinasi. Dengan ini pengendara memerlukan suatu informasi tentang ketersediaan tempat parkir yang tersedia di sekitar destinasi sebelum sampai di destinasi. Maka sistem manajemen parkir sangat diperlukan untuk menyediakan informasi tentang tempat parkir yang tersedia sekitar destinasi. Salah satunya cara yang dapat dilakukan adalah dengan menggunakan prinsip Location Based Service (LBS) untuk menyediakan informasi tempat parkir sekitar lokasi destinasi dengan menampilkannya posisi latitude and longitude dari posisi tempat parkir dalam bentuk peta digital menggunakan Google Maps API. Dan setiap ruang parkir pada tempat parkir diidentifikasi menggunakan QR-Code yang berisi kode unik setiap ruang parkir. Kemudian menggunakan Google Maps API untuk menyaring tempat parkir yang terdapat dalam radius terdekat dengan tempat destinasi dengan cara hanya memperlihatkan tempat parkir di dalam radius saja dan yang masih tersedia ruang parkirnya. Hasil pengujian memperlihatkan bahwa sistem manajemen parkir mobil on street dan off street berbasis location based service dan google maps api dapat bekerja dengan baik berdasarkan hasil akhir pengujian User Acceptance Test sebesar $93 \%$.
\end{abstract}

Kata kunci - Parkir On Street, Parkir Off Street, Latitude, Longitude, Location Based Service, Google Maps API, QRCode

\section{Pendahuluan}

Parkir adalah keadaan tidak bergerak suatu kendaraan yang bersifat sementara karena ditinggalkan oleh pengemudinya. Secara hukum dilarang untuk parkir di tengah jalan raya, namun parkir di sisi jalan umumnya diperbolehkan. Fasilitas parkir dibangun bersama-sama dengan kebanyakan gedung, untuk memfasilitasi kendaraan pemakai gedung. Termasuk dalam pengertian parkir adalah setiap kendaraan yang berhenti pada tempattempat tertentu baik yang dinyatakan dengan rambu lalu lintas ataupun tidak, serta tidak semata-mata untuk kepentingan menaikkan dan/atau menurunkan orang dan/atau barang [1].

Parkir memerlukan suatu lahan / tempat parkir yang dapat menampung kendaraan yang ingin diparkirkan seperti tempat parkir di bahu jalan maupun di gedung parkir. Maka setiap memarkirkan kendaraan, pengendara harus mencari terlebih dahulu di suatu tempat parkir yang masih tersedia ruang untuk dapat memarkirkan kendaraan pengendara.

Parkir merupakan hal penting ketika berpergian kemana-mana, terutama tempat parkir mobil dengan semakin banyaknya pengendara mobil pribadi saat ini, seringkali menyebabkan padatnya tempat parkir mobil dan menyebabkan keterbatasan tempat parkir. Dan ini pengendara diharuskan mencari tempat parkir yang tersedia. Jika terjadi kepadatan tempat parkir di tepi jalan maka pengendara harus mencari secara perlahan, yang dapat menyebabkan kemacetan jalan. Sedangkan jika terjadi kepadatan tempat parkir di dalam bangunan maka pengendara harus menyusuri setiap lantai parkir, dan ini dapat memakan waktu yang lama.

Hal itu disebabkan pengendara tidak mengetahui ketersediaan tempat parkir yang berada di sekitar destinasi dan membuat pengendara harus mencarinya setelah sampai destinasi. Dengan ini pengendara memerlukan suatu informasi tentang ketersediaan tempat parkir yang tersedia di sekitar destinasi. Supaya pengendara dapat mengetahui tempat parkir yang dapat memarkirkan kendaraan pengendara tanpa harus mencarinya pada saat sudah di suatu tempat parkir. 
Tetapi adapun kendala yang dari juru parkir dan pengelola parkir untuk dapat menyediakan informasi ketersediaan tempat parkir bagi setiap pengendara yaitu tidak ada media untuk menginformasikan ketersediaan tempat parkir dan tidak ada penanda akan ketersediaan ruang parkir yang bisa digunakan. Maka sistem manajemen parkir sangat diperlukan untuk menyediakan informasi tentang tempat parkir yang tersedia sekitar destinasi. Hal itu dapat dicapai salah satunya dengan menggunakan prinsip Location Based Service (LBS) untuk menyediakan informasi tempat parkir sekitar lokasi destinasi [2].

Dengan menerapkan prinsip LBS informasi tempat parkir di sekitar lokasi destinasi dengan menampilkannya dalam bentuk peta digital menggunakan Google Maps API [3]. Dengan menampilkan tempat parkir yang berada dalam radius tertentu sekitar lokasi destinasi. Pengemudi dapat memilih dan memesan salah satu tempat parkir yang dekat dengan lokasi destinasi.

Dengan Google Maps API, sistem dapat menampilkan posisi latitude and longitude dari posisi tempat parkir dalam bentuk peta digital [4]. Peta digital tersebut dapat membantu dalam visualisasi tempat-tempat parkir yang berada disekitar lokasi destinasi. Google Maps API juga dapat memfasilitasi sistem untuk menyaring tempat parkir yang terdapat dalam radius terdekat dengan tempat destinasi dengan cara hanya memperlihatkan tempattempat parkir di dalam radius saja dan yang masih tersedia tempat parkirnya.

Dengan latitude and longitude dari posisi tempat parkir yang tercatat dalam sistem maka pencarian tempat parkir dalam radius tertentu dari lokasi destinasi dapat tercapai. Akan tetapi dengan menggunakan latitude dan longitude mempunyai keterbatasan yaitu harus berada di lokasi yang terbuka saja. Sedangkan pada kondisi tempat parkir yang berada di dalam gedung penerapan LBS, posisi latitude dan longitude dari tempat parkir dapat mengalami masalah yaitu tempat parkir yang bertingkat tidak dapat mewakili setiap tempat parkir di gedung bertingkat. Salah satu solusi yang mungkin diterapkan adalah $Q R$ Code. Selama ini $Q R$-Code dipakai untuk identifikasi, metode pembayaran dan lain-lain [5]. QR-Code juga dapat diterapkan pada tempat parkir sebagai penanda unik setiap tempat parkir di lokasinya maupun dalam sistem.

Dengan lokasi tempat parkir sudah dapat diidentifikasi menggunakan latitude, longitude dan $Q R$-code, maka penunjukan arah (direction) menuju tempat parkir pun dapat dilakukan. Penunjukan arah tersebut dapat diterapkan menggunakan Google Maps Direction API dan GPS dari mobile device setiap pengendara. Google Maps Direction API menampilkan arah menuju tempat parkir pada peta digital dan GPS dari mobile device setiap pengendara dapat menampilkan lokasi keberadaan setiap pengendara.

Untuk menjamin ketersediaan tempat parkir maka perlu diterapkan sistem pemesanan (Booking). Sistem pemesanan ini memungkinkan pengendara untuk memesan tempat parkir sebelum sampai di lokasi tempat parkir, ini dapat memudahkan pengendara mendapatkan tempat parkir di sekitar destinasi. Biaya pemesanan tempat parkir dapat menggunakan sistem saldo. Biaya pemesanan ini digunakan untuk memastikan pengendara akan benar-benar memakai tempat parkir tersebut.

Sistem saldo selain untuk pembayaran biaya pemesanan tempat parkir, sistem saldo ini juga dapat digunakan untuk pembayaran biaya parkir. Sistem saldo dibangun juga akan memberi kemudahan pengendara dalam pembayaran biaya parkir tanpa menggunakan uang tunai, ini dapat dicapai dengan cara melakukan pengisian (top up) saldo sebelum melakukan pemesanan tempat parkir. Pengisian saldo dapat dilakukan dengan cara transfer bank.

Dengan demikian, jika pengendara dapat mengetahui tentang ketersediaan tempat parkir mobil sekitar lokasi destinasi, memesan tempat parkir dan membayar biaya parkir secara online. Maka pengendara mobil dapat leluasa bepergian tanpa harus khawatir mencari tempat parkir lagi. Oleh karena itu, penulis bermaksud mengembangkan Sistem Manajemen Parkir Mobil On Street dan Off Street Berbasis Location Based Service (LBS) dan Google Maps API.

\section{LANDASAN TEORI}

\section{A. Pengertian Parkir}

Menurut PP No. 43 tahun 1993 parkir didefinisikan sebagai kendaraan yang berhenti pada tempat-tempat tertentu baik yang dinyatakan dengan rambu atau tidak, serta tidak semata-mata untuk kepentingan menaikkan atau menurunkan orang dan atau barang. Sedangkan definisi lain tentang parkir adalah keadaan dimana suatu kendaraan berhenti untuk sementara (menurunkan muatan) atau berhenti cukup lama. Sehingga tempat parkir ini harus ada pada saat akhir atau tujuan perjalanan sudah dicapai [6].

Parkir adalah tempat pemberhentian kendaraan dalam jangka waktu pendek atau lama, sesuai dengan kebutuhan pengendara. Parkir merupakan salah satu unsur prasarana transportasi yang tidak terpisahkan dari sistem jaringan transportasi, sehingga pengaturan parkir akan mempengaruhi kinerja suatu jaringan, terutama jaringan jalan raya [7].

Menurut penempatanya, jenis parkir dapat terbagi menjadi dua jenis antara lain [7]:

1. Parkir di tepi jalan (on-street parking). Yakni parkir dengan menggunakan badan jalan sebagai tempat parkir.

2. Parkir di luar badan jalan (off-street parking). Yakni parkir kendaraan di luar badan jalan bisa di halaman gedung perkantoran, supermarket, atau pada taman parkir.

\section{B. Location Based Service}

Location Based Service (LBS) merupakan suatu layanan yang bereaksi aktif terhadap perubahan entitas posisi sehingga mampu mendeteksi letak objek dan 
memberikan layanan sesuai dengan letak objek yang telah diketahui tersebut. Location Base Services adalah aplikasi yang bergantung pada pada lokasi tertentu dan didefinisikan pula sebagai layanan informasi dengan memanfaatkan teknologi untuk mengetahui posisi sesuatu. Layanan berbasis lokasi menggunakan teknologi Positioning System, teknologi ini memungkinkan para pengguna dapat memperoleh informasi lokasi sesuai dengan kebutuhannya [2]. Dengan menerapkan LBS pada sistem ini, sistem dapat memyediakan informasi tempat parkir yang tersedia di sekitar lokasi destinasi yang dituju.

Untuk menggambarkan cara kerja LBS, anggaplah aplikasi LBS akan mencarikan informasi mengenai lokasi restoran yang berada di sekitar posisi pengguna [8].

1. Anggaplah sekarang fungsi pencarian telah diaktifkan, posisi pengguna sebenarnya dari perangkat mobile diperoleh dari Positioning Service. Hal ini dapat dilakukan baik oleh perangkat menggunakan GPS sendiri atau layanan posisi jaringan yang berasal dari provider (Cell Tower). Setelah itu perangkat mobile pengguna mengirimkan permintaan informasi, yang berisi tujuan untuk mencari dan mengirimkan posisi melalui jaringan komunikasi ke gateway telekomunikasi.

2. Gateway memiliki tugas untuk bertukar pesan di antara jaringan komunikasi selular dan internet. Oleh karena itu dia mengetahui alamat web dari beberapa aplikasi server dan rute permintaan ke spesifik server tertentu. Gateway akan menyimpan juga informasi tentang perangkat mobile yang telah meminta informasi

3. Aplikasi server membaca permintaan dan mengaktifkan layanan yang terkait.

4. Kemudian, service menganalisis lagi pesan dan memutuskan mana informasi tambahan selain criteria pencarian (restoran + padang) dan posisi pengguna diperlukan untuk menjawab permintaan pengguna. Dalam kasusu ini service akan menemukan bahwa pengguna membutuhkan informasi tentang restoran daridatabase yellow pages pada wilayah tertentu dan kemudian service tersebut akan meminta penyedia data untuk memberikan data tersebut

5. Selanjutnya service akan menemukan bahwa informasi tentang jalan, jarak dan cara yang diperlukan untuk memeriksa apakah restoran dapat dicapai

6. Setelah sekarang semua informasi service akan melakukan buffer spasial dan query routing untuk mendapatkan beberapa restoran terdekat. Setelah menghitung daftar restoran terdekat, hasil dikirim kembali ke pengguna melalui internet, gateway dan jaringan mobile.

7. Kemudian, informasi mengenai restoran akan disampaikan kepada pengguna baik dalam bentuk peta digital.

\section{Google Maps API}

Google Maps Application Programming Interface (API) merupakan suatu fitur aplikasi yang dikeluarkan oleh google untuk memfasilitasi pengguna yang ingin mengintegrasikan Google Maps ke dalam website masingmasing dengan menampilkan data point milik sendiri. Dengan menggunakan Google Maps API, Google Maps dapat di-embed pada website eksternal. Agar aplikasi Google Maps dapat muncul di website tertentu, diperlukan adanya API key. API key merupakan kode unik yang digenerasikan oleh google untuk suatu website tertentu, agar server Google Maps dapat mengenali, namun untuk Google Maps API versi 3 sudah tidak membutuhkan API key, sehingga mempermudah untuk menggunakan Google Maps API, dan pada versi ini juga terdapat beberapa perbedaan sintaks dari kode yang digunakan [3]. Dengan Google Maps API, sistem dapat menampilkan posisi latitude and longitude dari posisi tempat parkir dalam bentuk peta digital. Peta digital tersebut dapat membantu dalam visualisasi tempat-tempat parkir yang berada disekitar lokasi destinasi.

\section{Latitude dan Longitude}

Latitude adalah garis yang melintang di antara kutub utara dan kutub selatan, yang menghubungkan antara sisi timur dan barat bagian bumi. Garis ini memiliki posisi membentangi bumi, sama halnya seperti garis equator (khatulistiwa), tetapi dengan kondisi nilai tertentu. Garis lintang inilah yang dijadikan ukuran dalam mengukur sisi utara-selatan koordinat suatu titik di belahan bumi. Sedangkan longitude adalah garis membujur yang menghubungkan antara sisi utara dan sisi selatan bumi (kutub). Garis bujur ini digunakan untuk mengukur sisi barat-timur koordinat suatu titik di belahan bumi. Sama seperti equator pada latitude yang berada ditengah dan memiliki nilai 0 (nol) derajat, pada longitude, garis tengah yang bernilai 0 (nol) derajat disebut garis prime meridian (garis bujur). Sedangkan garis yang berada paling kiri memiliki nilai -90 derajat, dan yang paling kanan memiliki nilai 90 derajat [4]. Dengan Latitude dan Longitude, dapat diterapkan pada sistem ini sebagai format penyimpanan letak keberadaan tempat parkir dalam sistem

\section{E. Quick Response Code}

Quick Response Code (QR-Code) adalah jenis barcode yang berbentuk dua dimensi yang dikembangkan oleh Denso Wave, sebuah divisi Denso Corporation, sebuah perusahaan di Jepang, yang dipublikasikan pada tahun 1994. QR merupakan singkatan dari Quick Response (respon / tanggapan cepat), sehingga fungsi atau tujuan utama dari teknologi ini adalah penyampaian informasi dengan cepat dan mendapat tanggapan atau respons yang cepat pula. Oleh karena itu $Q R$-code dapat dengan mudah dibaca oleh pemindai. Berbeda dengan barcode biasa yang berbentuk satu dimensi dan menyimpan informasi secara horizontal, $Q R$-code mampu menyimpan informasi secara horizontal dan vertikal. $Q R$-code juga mampu menyimpan teks alfanumerik, kanji, kana, hiragana, simbol, biner, url, 
dan control code. Adapun contoh dari $Q R$ Code yang dituangkan dalam Gambar 1. yang berisi https://google.com [5]. Dengan $Q R$-Code dapat diterapkan pada sistem ini sebagai penanda unik setiap tempat parkir di lokasinya maupun dalam sistem.

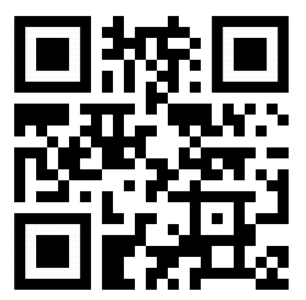

Gambar. 1 Contoh QR code

\section{F. Unified Modeling Language}

Unified Model Language (UML) adalah sebuah 'bahasa' yang telah menjadi standar dalam industri untuk visualisasi, merancang dan mendokumentasikan sistem piranti lunak [9]. UML (Unified Modeling Language) adalah standar bahasa yang banyak digunakan di dunia industri untuk mendefinisikan requirement, membuat analisis dan desain, serta menggambarkan arsitektur dalam pemrograman berbasis objek [10]. Berdasarkan definisi tersebut dapat disimpulkan bahwa UML adalah standar bahasa komunikasi yang digunakan industri untuk membuat perancangan, analisis, desain, dan dokumentasi dalam pembuatan sistem piranti lunak. Dengan UML, perancangan sistem ini dapat lebih terstruktur.

\section{G. Black Box Testing}

Black box testing adalah tipe testing yang memerlukan perangkat lunak yang tidak diketahui kinerja internalnya. Sehingga para tester memandang perangkat lunak seperti layaknya sebuah "kotak hitam" yang tidak penting dilihat isinya, tapi dikenal proses testing di bagian luar. Jenis testing ini hanya memandang perangkat lunak dari sisi spesifikasi dan kebutuhan yang telah didefinisikan pada saat awal perancangan. Sebagai contoh, jika terdapat sebuah perangkat lunak yang merupakan sebuah sistem informasi inventory sebuah perusahaan. Maka pada jenis white box testing, perangkat lunak tersebut akan berusaha dibongkar listing programnya untuk kemudian di tes menggunakan teknik-teknik yang telah dijelaskan sebelumnya. Sedangkan pada jenis black box testing, perangkat lunak tersebut akan dieksekusi kemudian berusaha dites apakah telah memenuhi kebutuhan pengguna yang didefinisikan pada awal tanpa harus membongkar listing programnya [11]. Dengan Black Box Testing, sistem ini dapat diuji apakah fitur-fitur atau kebutuhan-kebutuhan fungsional telah terpenuhi dan berjalan dengan lancar.

\section{H. User Acceptance Testing}

User Acceptance Testing merupakan pengujian yang dilakukan oleh end-user dimana user tersebut adalah staf/karyawan perusahaan yang langsung berinteraksi dengan sistem dan dilakukan verifikasi apakah fungsi yang ada telah berjalan sesuai dengan kebutuhan/fungsinya. User Acceptance Testing adalah metode testing dimana pengguna akhir melakukan percobaan untuk memvalidasi produk berdasarkan kebutuhan yang telah ditentukan. Pengujian ini bertujuan untuk membantu menemukan bug yang akan muncul pada saat penggunaan [12]. Dengan User Acceptance Testing, sistem dapat diuji oleh end-user (pengguna), agar mendapat penilaian terhadap sistem ini.

\section{Hypertext Markup Language (HTML)}

Hypertext Markup Language (HTML) merupakan bahasa struktur untuk membuat sebuah teks menjadi link yang dapat berpindah dari satu halaman ke halaman lainnya hanya dengan meng-klik teks tersebut dan menggunakan tanda (dalam bahasa inggris disebut 'mark') untuk menandai bagian - bagian dari teks agar teks tersebut memiliki tampilan dan fungsi tertentu. Sebagai contoh, teks yang berada di antara tanda (mark) tertentu akan menjadi tebal, miring, dan berwarna merah. Dan, jika berada diantara tanda lainnya, maka membuat teks tersebut menjadi sebuah link yang dapat di-klik. Dalam praktiknya nanti, tanda atau mark tersebut disebut dengan istilah Tag [13]. HTML dapat digunakan sebagai bahasa markup untuk mengstruktur tampilan dalam mengembangkan sistem.

\section{J. Cascading Style Sheet}

Cascading Style Sheet (CSS) merupakan kumpulan kode untuk mendesain atau mempercantik tampilan halaman. Dengan arti lain, dengan memanfaatkan CSS kita bisa mengubah desain standar yang dihasilkan oleh HTML menjadi variasi-variasi yang lebih kompleks. Dengan CSS-lah, sebuah desain website yang dibangun menggunakan HTML akan menjadi lebih menarik dan variatif [13]. CSS dapat digunakan untuk mempercantik tampilan dalam sistem.

\section{K. JavaScript}

JavaScript adalah script default di HTML. Meskipun namanya berbau Java, Javascript dan Java adalah dua bahasa pemrograman yang berbeda. Bersama HTML dan CSS, Javascript menjadi tiga teknologi paling utama dalam pembuatan konten website. Javascript sudah didukung oleh berbagai browser modern, sehingga tidak membutuhkan plug-ins apapun. Melalui Javascript Anda bisa mengubah konten halaman web, mengubah attribute tag HTML, mengubah aturan style di CSS, atau memvalidasi form yang telah diinput pengunjung sebelum mengirimkannya ke web server. Anda juga sering memasang kode-kode Javascript saat ingin menampilkan iklan atau widget pada halaman web Anda nantinya [14]. JavaScript dapat digunakan untuk membuat tampilan lebih interaktif dalam sistem.

\section{PHP Hypertext Preprocessor}


PHP merupakan bahasa pemrograman yang digunakan untuk membuat aplikasi berbasis website. Sebagai sebuah aplikasi, website tersebut hendaknya memiliki sifat dinamis dan interaktif. memiliki sifat dinamis artinya, website tersebut bisa berubah tampilan kontennya sesuai kondisi tertentu (misalnya, menampilkan produk yang berbeda-beda untuk setiap pengunjung). Interaktif artinya, website tersebut dapat memberi feedback bagi user (misalnya, menampilkan hasil pencarian produk) [15]. Dengan PHP dapat digunakan untuk membuat tampilan yang dinamis dalam sistem.

\section{MySQL}

MySQL adalah RDBMS yang cepat dan mudah digunakan, serta sudah banyak dipakai untuk berbagai kebutuhan. MySQL dikembangkan oleh MySQL AB Swedia. Hampir sebagian besar aplikasi website yang ada di internet dikembangkan menggunakan MySQL dan bahasa pemrograman lainnya, seperti PHP [16]. MySQL dapat digunakan untuk menyimpan data-data dengan cepat dan mudah dalam sistem.

\section{N. Laravel Framework}

Laravel adalah Framework PHP yang dirilis dibawah lisensi MIT dan dibangun dengan konsep MVC (ModelView-Controller). Laravel adalah pengembangan MVC yang ditulis dalam PHP yang dirancang untuk meningkatkan kualitas perangkat lunak dengan mengurangi biaya pengembangan awal dan biaya pemeliharan, serta untuk meningkatkan pengalaman bekerja dengan aplikasi dengan menyediakan sintaks yang ekspresif, jelas, dan menghemat waktu [17]. Laravel dapat digunakan untuk mempersingkat dan mempermudah pengembangan sistem.

\section{ANALSIS DAN PERANCANGAN SISTEM}

\section{A. Analisis Proses}

Adapun prinsip yang diimplementasikan di dalam sistem manajemen parkir yaitu Location Based Service (LBS). LBS merupakan suatu layanan yang bereaksi aktif terhadap perubahan entitas posisi sehingga mampu mendeteksi letak objek dan memberikan layanan sesuai dengan letak objek yang telah diketahui tersebut. Dengan penerapan LBS dalam sistem manajemen parkir mobil, sistem dapat menyajikan tempat-tempat parkir yang tersedia di sekitar destinasi tujuan. Penyajian tempattempat parkir tersebut di dalam peta digital dengan memanfaatkan Google Maps API. Pencarian tempat parkir di sekitar destinasi bisa dilakukan dengan adanya penyimpanan lokasi GPS setiap tempat parkir, yang dibandingkan dengan letak GPS smartphone setiap pengendara mobil. Pengenalan ketersediaan ruang parkir setiap tempat parkir dapat diterapkan dengan melakukan pencatatan setiap pemesanan dan pemakaian setiap ruang parkir serta dibantu dengan terdapatnya kode unik dan $q r$ code di setiap ruang parkir. Kode unik dan $Q R$-Code ini yang merepresentasikan setiap ruang parkir di dalam sistem dan juga penandaan setiap ruang parkir di lapangan.

\section{B. Analisis Sistem Berjalan}

Sebagian besar sistem-sistem manajemen parkir mobil yang sudah berjalan saat ini untuk On Street (bahu jalan) dan Off Street (gedung parkir) pada umum berupa manajemen parkir mobil di baju jalan yang dikelola oleh juru parkir / tukang parkir dan manajemen parkir mobil di gedung parkir yang memakai karcis parkir dilengkapi dengan penampilan jumlah parkir yang masih tersedia pada layar monitor di luar gedung parkir.

\section{Sistem yang Akan Dibangun}

Berdasarkan analisis sistem yang sedang berjalan maka diperlukan sistem manajemen parkir yang meliputi pencarian, pemesanan dan penggunaan tempat parkir yang tersedia, serta pengolahan data tempat parkir, yang mana proses secara umum yang dirancang lebih kurangnya seperti berikut ini:

1. Pengguna

a. Melakukan registration pada sistem.

b. Melakukan login ke dalam sistem.

c. Mengisi ulang saldo melalui transfer bank.

d. Mendaftarkan kendaraan mobil pengguna.

e. Melihat tampilan peta dalam bentuk peta digital

f. Mencari tempat parkir di sekitar destinasi dengan mencari lokasi destinasinya atau memilihnya dalam peta digital.

g. Mendapat tempat-tempat parkir yang masih memiliki ruang parkir yang tersedia di sekitar destinasi pengguna dalam radius kurang lebih 200 meter.

h. Memilih dan memesan tempat parkir parkir dan ruang parkir yang sesuai dengan keinginan untuk durasi tertentu.

i. Mendapatkan petunjuk arah menuju tempat parkir yang telah dipilih.

j. Memindai QR-Code yang terdapat di ruang parkir yang telah pesan sesampainya di tempat parkir tersebut.

k. Memindai QR-Code yang terdapat di ruang parkir yang telah pesan sebelum pergi dari tempat parkir tersebut.

1. Mengubah profil dan kata sandi pengguna.

m. Melakukan logout.

2. Administrator

a. Melakukan login ke dalam sistem.

b. Melihat daftar pengguna.

c. Mendaftarkan operator lapangan / juru parkir.

d. Melihat daftar mobil.

e. Melihat daftar tempat parkir dan ruang parkir.

f. Mendaftarkan tempat parkir.

g. Mengubah profil dan kata sandi administrator.

h. Melakukan logout.

3. Admin Operator

a. Melakukan login ke dalam sistem.

b. Mendaftarkan daftar ruang parkir. 
c. Melihat daftar pemakaian parkir dan pemesanan parkir.

d. Mengubah profil dan kata sandi operator.

e. Melakukan logout.

4. Operator

a. Melakukan login ke dalam sistem.

b. Melihat daftar pemakaian parkir dan pemesanan parkir.

c. Mengubah profil dan kata sandi operator.

d. Melakukan logout.

\section{Arsitektur Sistem}

Adapun arsitektur sistem manajemen parkir yang dapat dilihat pada Gambar 2.

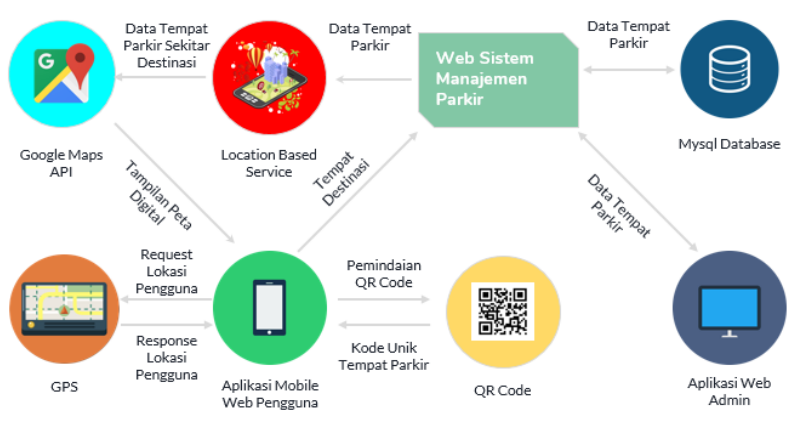

Gambar. 2 Arsitekur sistem 2:

Arsitektur sistem seperti yang dipaparkan pada Gambar

1. Pertama dalam sistem manajemen parkir ini memiliki tampilan antarmuka serba guna, dapat sebagai aplikasi web admin maupun aplikasi mobil web pengguna. Dari situ aplikasi web admin memiliki fitur menambah informasi tempat parkir. Penambahan dan penampilan informasi tempat parkir akan disimpan di database mysql.

2. Kedua, ketika pengguna mencari tempat parkir di sekitar destinasi. Kemudian sistem akan mencarinya dengan prinsip location based service. Sistem akan menampilkan layanan tempat parkir yang masih tersedia di lokasi destinasi dan memvisualisasikan nya dengan peta digital menggunakan google maps api.

3. Seterusnya pengguna akan memilih tempat parkir sesuai dengan keinginannya. Kemudian sistem akan menunjukkan arahan menuju tempat parkir dengan menggunakan GPS. Untuk mengetahui lokasi pengendara dan menampilkan jalur nya di peta digital.

4. Setelah pengendara sampai di tempat parkir, pengendara akan memindai $q r$ code yang ada di tempat parkir yang dipesannya sebagai tanda pengendara telah sampai ditempat parkir dan sebagai tanda tempat parkir sedang terpakai.

\section{E. Rancangan Fungsional}

Adapun rancangan fungsional menggunakan Use Case Diagram untuk menggambarkan hal-hal yang dapat dilakukan aktor-aktor di dalam sistem. Rancangan ini dapat dilihat pada Gambar 3.

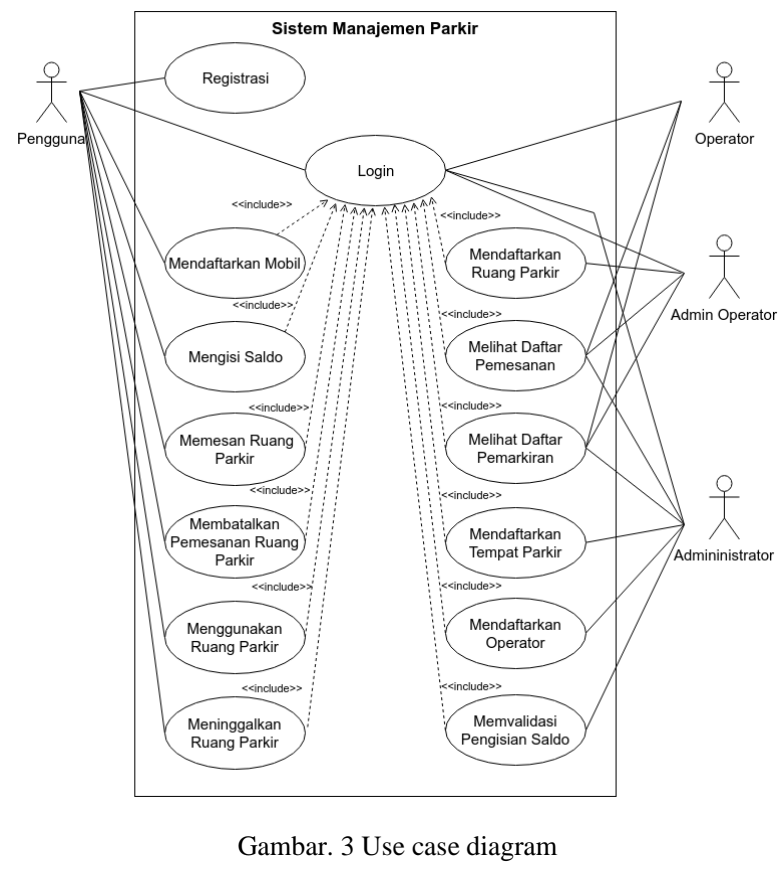

Di dalam use case diagram diatas terdapat empat aktor yang berperan dalam sistem manajemen parkir, yaitu pengguna, admin operator, operator dan administrator. Use case yang terdapat di dalam sistem seperti berikut ini:

1. Pengguna

a. Registrasi

b. Login

c. Mendaftarkan saldo

d. Mengisi saldo

e. Memesan ruang parkir

f. Membatalkan pemesanan ruang parkir

g. Menggunakan ruang parkir

h. Meninggalkan ruang parkir

2. Administrator
a. Login
b. Mendaftarkan operator
c. Mendaftarkan tempat parkir
d. Menvalidsai pengisian saldo
e. Melihat daftar pemesanan
f. Melihat daftar pemarkiran

3. Admin Operator
a. Login
b. Mendaftarkan ruang parkir
c. Melihat daftar pemesanan
d. Melihat daftar pemarkiran

4. Operator
a. Login
b. Melihat daftar pemesanan
c. Melihat daftar pemarkiran 


\section{F. Rancangan Tampilan}

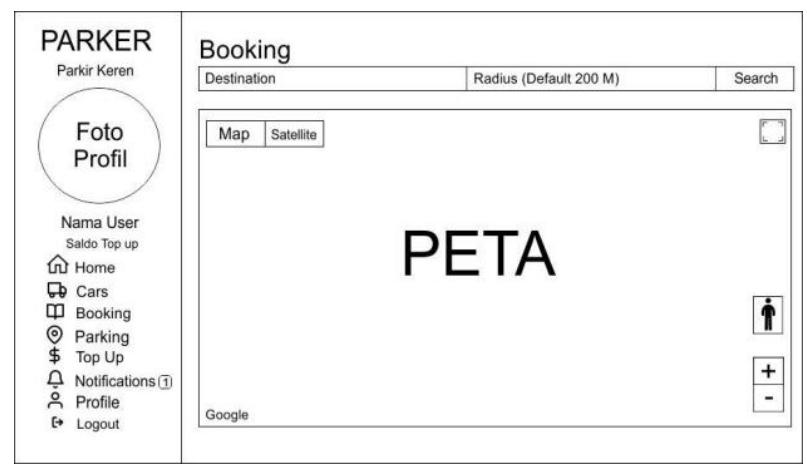

Gambar. 4 Perancangan halaman pemesanan ruang parkir

Rancangan tampilan yang dirancang untuk halaman pemesanan ruang parkir yang tersedia (Gambar 4). Rancangan ini terdiri dari menu sidebar, input teks untuk mengisi destinasi dan peta digital untuk menampilkan tempat-tempat parkir di sekitar destinasi yang masih tersedia ruang parkirnya.

\section{IMPLEMENTASI DAN HASIL PENGUJIAN}

\section{A. Implementasi}

Hasil rancangan sistem memiliki kemampuan untuk melakukan pencarian dan pemesanan ruang parkir. Tampilan dari sistem yang telah dirancang dapat dilihat pada Gambar 5.

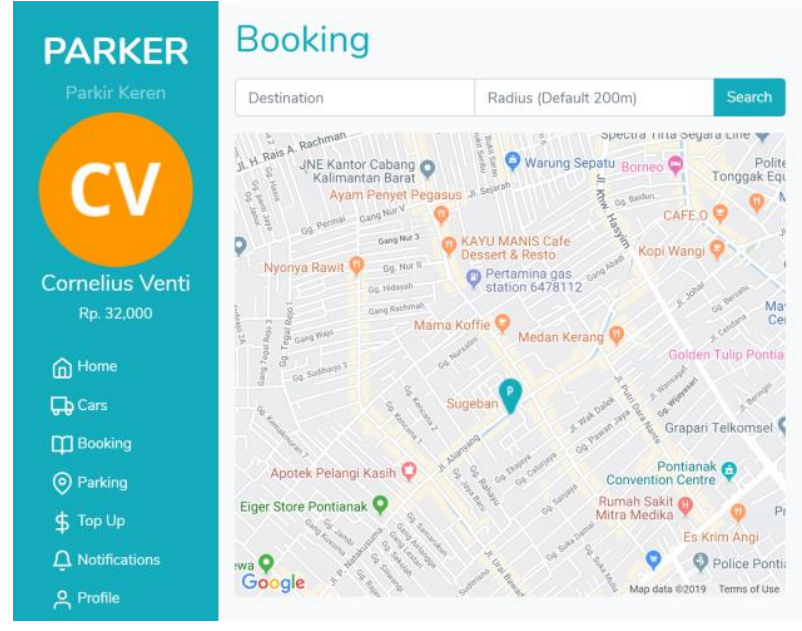

Gambar. 5 Halaman pemesanan ruang parkir

Tampilan halaman pemesanan untuk pengguna dapat mendapatkan informasi ketersediaan ruang parkir, mencari tempat parkir di sekitar destinasi dan memesan dan memesan ruang parkir pada suatu tempat parkir di sekitar destinasi.

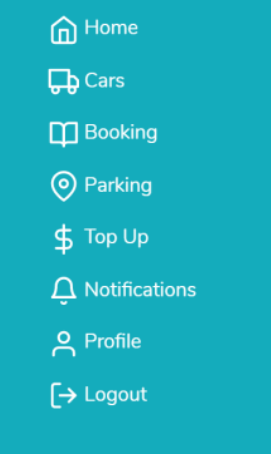

Gambar. 6 Menu-menu pada sistem

Dimulai dari menu-menu pada sistem manajemen parker (Gambar 6), terdiri dari:

a. Home, tampilan dashboard.

b. Car, fitur yang digunakan untuk memasukkan no plat dan merek kendaraan pengguna sebelum melakukan pemesanan.

c. Booking, fitur yang digunakan untuk melakukan pemesanan parkir.

d. Parking, fitur yang digunakan untuk melakukan penggunaan parkir.

e. Top Up, fitur yang digunakan untuk mengirimkan sebagian dana yang diperlukan dari rekening pengguna ke akun sistem manajemen parkir sebelum melakukan pemesanan.

f. Notification, fitur yang digunakan untuk memberikan informasi kepada pengguna jika pemesanan yang telah dilakukan dalam keadaan masih berlaku atau tidak dan memberikan rincian pemesanan.

g. Profile, fitur yang digunakan untuk mengatur nama, foto, email, dan untuk mengubah password sebelumnya.

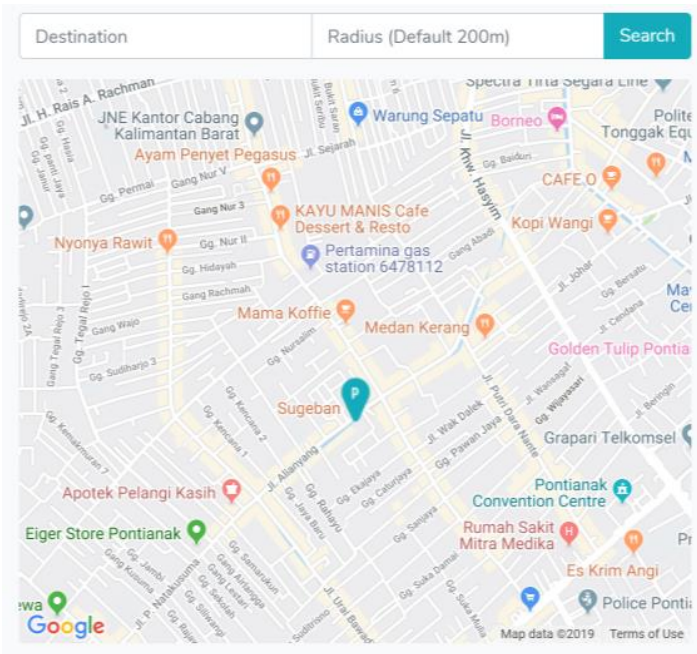

Gambar. 7 Pencarian tempat parkir

Pencarian tempat parker (Gambar 7) merupakan bagian dari halaman pemesanan untuk pengguna dapat 
mendapatkan informasi ketersediaan ruang parkir dan mencari tempat parkir di sekitar destinasi yang tersedia ruang parkir. Dengan cara memasukan memasukan destinasi di input text destinasi dan radius pencarian tempat parkir di sekitar destinasi (standar 200 meter).

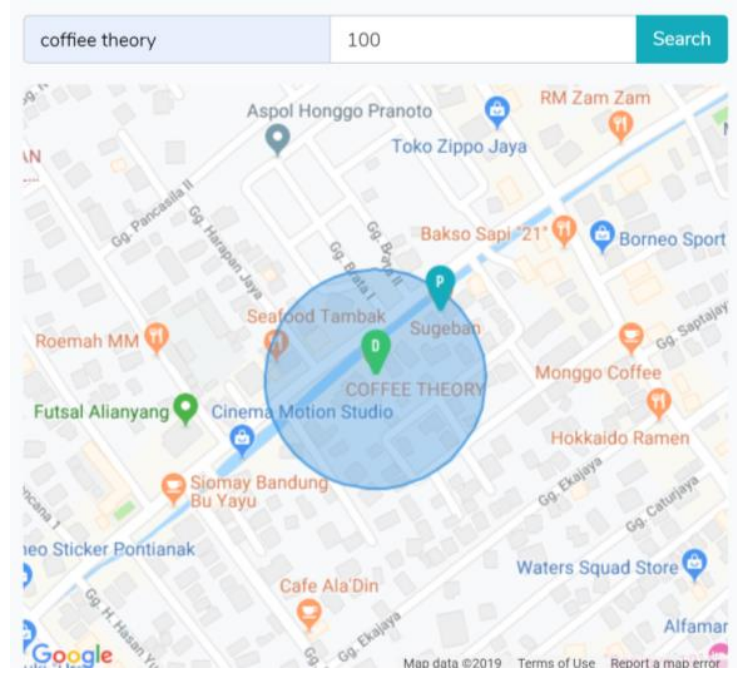

Gambar. 8 Pemilihan tempat parkir

Pemilihan tempat parkir (Gambar 8) merupakan bagian dari halaman pemesanan untuk memilih tempat parkir yang telah di saring tempat parkir yang terdapat di sekitar destinasi dan radius yang pengguna masukan, serta tempat parkir yang masih tersedia ruang parkirnya. Kemudian pengguna dapat memilih salah satu tempat parkir yang ada.

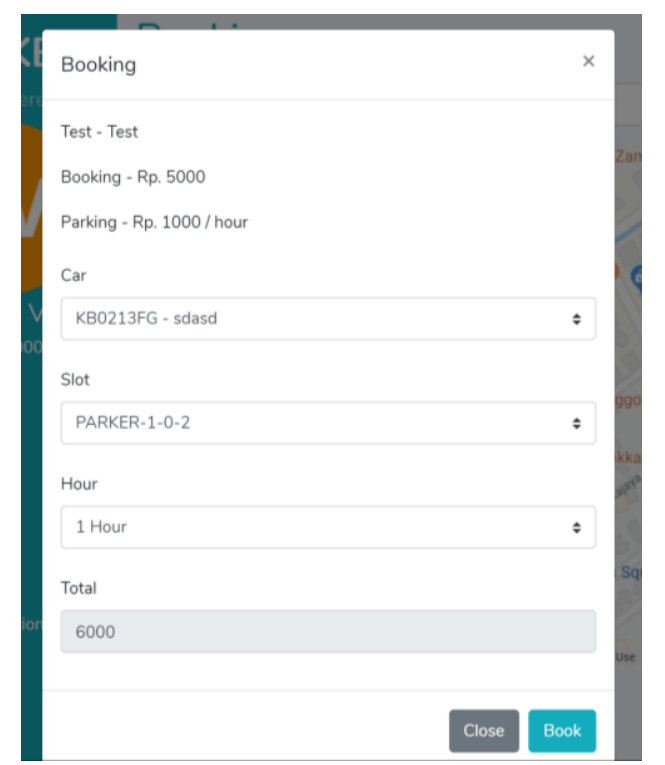

Gambar. 9 Pemesanan Ruang Parkir

Pemilihan tempat parkir merupakan bagian dari halaman pemesanan untuk memilih tempat parker (Gambar 9) yang telah di saring tempat parkir yang terdapat di sekitar destinasi dan radius yang pengguna masukan, serta tempat parkir yang masih tersedia ruang parkirnya. Kemudian pengguna dapat memilih salah satu tempat parkir yang ada.

\section{B. Hasil Pengujian}

Pengujian sistem manajemen parkir dilakukan untuk memastikan bahwa aplikasi yang dibangun telah sesuai dengan rancangan yang dibuat. Pengujian yang digunakan untuk menguji sistem ini adalah metode pengujian Black Box dan User Acceptance Test. Pengujian sistem manajemen parkir menggunakan metode black box akan ditampilkan dalam bentuk kasus uji - kasus uji sedangkan untuk user acceptance test akan ditampilkan dalam bentuk pertanyaan - pertanyaan yang sudah dibuat dan dijawab oleh pengguna sistem ini.

TABEL I

Pengujian Black Box Testing

\begin{tabular}{|c|c|c|c|c|}
\hline No & Kasus Uji & $\begin{array}{c}\text { Hasil yang } \\
\text { diharapkan }\end{array}$ & Hasil & $\begin{array}{l}\text { Ses } \\
\text { uai }\end{array}$ \\
\hline 1. & $\begin{array}{c}\text { Mendaftarkan } \\
\text { mobil }\end{array}$ & $\begin{array}{l}\text { Pengguna dapat } \\
\text { memasukan data mobil, } \\
\text { sistem dapat menambah } \\
\text { data, menginput mobil, } \\
\text { edit data dan hapus data }\end{array}$ & $\begin{array}{c}\text { Sistem dapat } \\
\text { melakukan create, } \\
\text { input, edit dan delete } \\
\text { dengan baik }\end{array}$ & $\begin{array}{l}\text { Ses } \\
\text { uai }\end{array}$ \\
\hline 2. & Mengisi saldo & $\begin{array}{l}\text { Ketika pengguna } \\
\text { memasukan informasi } \\
\text { pengisian saldo dan } \\
\text { bukti transfer, sistem } \\
\text { dapat menyimpan } \\
\text { informasi tersebut }\end{array}$ & $\begin{array}{l}\text { Sistem menyimpan } \\
\text { informasi pengisian } \\
\text { dan bukti transfer } \\
\text { dengan benar }\end{array}$ & $\begin{array}{l}\text { Ses } \\
\text { uai }\end{array}$ \\
\hline 3. & $\begin{array}{l}\text { Menyediakan } \\
\text { informasi } \\
\text { tempat parkir } \\
\text { yang tersedia }\end{array}$ & $\begin{array}{l}\text { Pengguna dapat } \\
\text { mencari tempat parkir } \\
\text { di sekitar destinasi, } \\
\text { sistem dapat } \\
\text { menampilkan tempat- } \\
\text { tempat parkir yang } \\
\text { tersedia ruang } \\
\text { parkirnya }\end{array}$ & $\begin{array}{l}\text { Sistem dapat mencari } \\
\text { tempat parkir di } \\
\text { sekitar destinasi dan } \\
\text { menampilkan tempat } \\
\text { parkir yang tersedia } \\
\text { ruang parkir }\end{array}$ & $\begin{array}{l}\text { Ses } \\
\text { uai }\end{array}$ \\
\hline 4. & $\begin{array}{l}\text { Memesan } \\
\text { ruang parkir }\end{array}$ & $\begin{array}{l}\text { Pengguna dapat } \\
\text { menginput pemesanan } \\
\text { ruang parkir dengan } \\
\text { benar }\end{array}$ & $\begin{array}{c}\text { Sistem menyimpan } \\
\text { pemesanan tempat } \\
\text { parkir }\end{array}$ & $\begin{array}{l}\text { Ses } \\
\text { uai }\end{array}$ \\
\hline 5. & $\begin{array}{l}\text { Membatalkan } \\
\text { pemesanan } \\
\text { ruang parkir }\end{array}$ & $\begin{array}{c}\text { Pengguna dapat } \\
\text { membatalkan } \\
\text { pemesanan ruang } \\
\text { parkir, sistem dapat } \\
\text { menghapus pemesanan } \\
\text { tersebut }\end{array}$ & $\begin{array}{c}\text { Sistem menghapus } \\
\text { pemesanan tempat } \\
\text { parkir }\end{array}$ & $\begin{array}{l}\text { Ses } \\
\text { uai }\end{array}$ \\
\hline 6. & $\begin{array}{c}\text { Melihat } \\
\text { arahan } \\
\text { menuju ruang } \\
\text { parkir }\end{array}$ & $\begin{array}{c}\text { Sistem dapat } \\
\text { menampilkan arahan } \\
\text { menuju ruang parkir } \\
\text { dalam bentuk peta } \\
\text { digital }\end{array}$ & $\begin{array}{c}\text { Sistem menampilkan } \\
\text { arahan menuju ruang } \\
\text { parkir }\end{array}$ & $\begin{array}{l}\text { Ses } \\
\text { uai }\end{array}$ \\
\hline 7. & $\begin{array}{l}\text { Menggunaka } \\
\text { n ruang } \\
\text { parkir }\end{array}$ & $\begin{array}{c}\text { Ketika pengguna } \\
\text { sampai di ruang parkir } \\
\text { dan memindai qr-code } \\
\text { nya, sistem dapat } \\
\text { menyimpan waktu } \\
\text { mulai penggunaan } \\
\text { ruang parkir tersebut. }\end{array}$ & $\begin{array}{c}\text { Sistem menyimpan } \\
\text { waktu mulai } \\
\text { penggunaan ruang } \\
\text { parkir }\end{array}$ & $\begin{array}{l}\text { Ses } \\
\text { uai }\end{array}$ \\
\hline 8. & $\begin{array}{l}\text { Meninggalka } \\
\text { n ruang } \\
\text { parkir }\end{array}$ & $\begin{array}{l}\text { Ketika pengguna } \\
\text { sebelum meninggalkan } \\
\text { ruang parkir dan }\end{array}$ & $\begin{array}{l}\text { Sistem menyimpan } \\
\text { waktu berakhirnya } \\
\text { penggunaan ruang }\end{array}$ & $\begin{array}{l}\text { Ses } \\
\text { uai }\end{array}$ \\
\hline
\end{tabular}




\begin{tabular}{|c|c|c|c|c|}
\hline No & Kasus Uji & $\begin{array}{c}\text { Hasil yang } \\
\text { diharapkan }\end{array}$ & Hasil & $\begin{array}{c}\text { Ses } \\
\text { uai }\end{array}$ \\
\hline & & $\begin{array}{c}\text { memindai qr-code nya, } \\
\text { sistem dapat } \\
\text { menyimpan waktu } \\
\text { berakhirnya penggunaa } \\
\text { n ruang parkir tersebut. }\end{array}$ & parkir & \\
\hline
\end{tabular}

Hasil dari setiap kasus uji pada pengujian Black Box pada Tabel I yang diuji dengan skenario pengujian, terdapat hasil yang diharapkan pada setiap kasus uji dan hasil yang didapat serta kesesuaian antara hasil yang diharapkan dengan hasil yang didapat.

TABEL II

PENGUJIAN USER ACCEPTANCE TEST

\begin{tabular}{|c|c|c|c|}
\hline No & Pertanyaan & Jumlah Nilai & $\begin{array}{l}\text { Persentase } \\
\quad \text { Nilai }\end{array}$ \\
\hline 1. & $\begin{array}{c}\text { Apakah tampilan pada sistem } \\
\text { manajemen parkir ini } \\
\text { menarik? }\end{array}$ & 47 & $94 \%$ \\
\hline 2. & $\begin{array}{l}\text { Apakah sistem ini mudah } \\
\text { digunakan / user friendly? }\end{array}$ & 47 & $94 \%$ \\
\hline 3. & $\begin{array}{c}\text { Apakah proses pengisian saldo } \\
\text { mudah dilakukan? }\end{array}$ & 47 & $94 \%$ \\
\hline 4. & $\begin{array}{l}\text { Apakah informasi tempat } \\
\text { parkir yang tersedia mudah } \\
\text { dimengerti? }\end{array}$ & 46 & $92 \%$ \\
\hline 5. & $\begin{array}{c}\text { Apakah proses pencarian } \\
\text { tempat parkir yang tersedia di } \\
\text { sekitar destinasi tujuan mudah } \\
\text { dilakukan? }\end{array}$ & 46 & $92 \%$ \\
\hline 6. & $\begin{array}{c}\text { Apakah proses pemesanan } \\
\text { ruang parkir pada tempat } \\
\text { parkir yang tersedia mudah } \\
\text { dilakukan? }\end{array}$ & 47 & $94 \%$ \\
\hline 7. & $\begin{array}{l}\text { Apakah proses pembatalan } \\
\text { pemesanan ruang parkir } \\
\text { mudah dilakukan? }\end{array}$ & 48 & $96 \%$ \\
\hline 8. & $\begin{array}{l}\text { Apakah arahan menuju tempat } \\
\text { parkir yang telah dipesan } \\
\text { mudah dimengerti? }\end{array}$ & 44 & $88 \%$ \\
\hline 9. & $\begin{array}{c}\text { Apakah proses pemindaian qr- } \\
\text { code ruang parkir mudah } \\
\text { dilakukan? }\end{array}$ & 46 & $92 \%$ \\
\hline 10. & $\begin{array}{l}\text { Apakah sistem manajemen } \\
\text { parkir ini sudah baik? }\end{array}$ & 47 & $94 \%$ \\
\hline
\end{tabular}

Hasil akhir dari pengujian User Acceptance Test pada Tabel II dapat diperoleh dengan cara merata-ratakan hasil rekap setiap pertanyaan dan dibagi dengan jumlah pertanyaan, yaitu $(70 \%+80 \%+70 \%+70 \%+70 \%+$ $80 \%+80 \%+50 \%+60 \%+80 \%) / 10=93 \%$.

\section{KESIMPULAN DAN SARAN}

A. Kesimpulan

Perancangan Sistem Manajemen Parkir Mobil On Street dan Off Street Berbasis Location Based Service dan Google Maps API bertujuan untuk menyediakan informasi ketersediaan tempat parkir di sekitar destinasi pengendara. Berdasarkan rancangan dan implementasi yang telah dilakukan dan diuraikan pada bab sebelumnya dalam penelitian ini, maka dapat disimpulkan sebagai berikut:

1. Sistem ini dapat menyediakan informasi ketersediaan ruang parkir pada tempat parkir di sekitar tempat destinasi.

2. Melalui sistem ini, pengguna / pengendara mobil dapat memesan ruang parkir pada tempat parkir yang tersedia di sekitar tempat destinasi.

3. Melalui sistem ini, pengendara mobil dapat mengikuti arahan menuju ruang parkir yang telah dipesan sebelumnya.

4. Dengan hasil akhir pengujian User Acceptance Test, maka dapat disimpulkan persentase penerimaan sistem manajemen parkir ini sebesar $93 \%$.

\section{B. Saran}

Dalam pembuatan Sistem Manajemen Parkir Mobil On Street dan Off Street Berbasis Location Based Service dan Google Maps API ini dapat dikembangkan dan ditambahkan fitur-fitur yang akan membuat sistem manajemen parkir ini menjadi lebih flexibel, seperti:

1. Sistem manajemen parkir ini dapat dikembangkan untuk memiliki fitur memesan ruang parkir lebih dari satu. Hal ini dikarenakan agar pengendara dapat memesankan tempat parkir untuk keluarganya atau temannya disaat bersamaan.

2. Sistem manajemen parkir ini dapat dikembangkan untuk memiliki fitur mengisi saldo dengan pengecekan otomatis, supaya pengendara bisa langsung melakukan pemesanan tanpa perlu menunggu konfirmasi dari administrator.

\section{REFERENSI}

[1] "Parkir." [Online]. Available: https://id.wikipedia.org/wiki/Parkir. [Accessed: 12-Aug-2019].

[2] B. Anwar, H. Jaya, and P. I. Kusuma, "Implementasi Locations Based Service Berbasis Android Untuk Mengetahui Posisi User," J. SAINTIKOM, vol. 13, no. 2, pp. 121-133, 2014

[3] M. Sholeh, N. Widyastuti, and A. Mashuri, "Aplikasi Google Maps API Untuk Sistem Informasi Geografis,” Juita, vol. 1, no. 3, 2011

[4] M. A. Novianta and E. Setyaningsih, "Sistem Informasi Monitoring Kereta Api Berbasis Web Server Menggunakan layanan GPRS,” Momentum, vol. 17, no. 2, pp. 58-67, 2015.

[5] R. Meimaharani, "E-Commerce Goody Bag Spunbond Menggunakan Qr Code Berbasis Web Responsif," Simetris J. Tek. Mesin, Elektro dan Ilmu Komput., vol. 5, no. 2, pp. 127-135, 2014.

[6] W. Suwardjoko, Merencanakan Sistem Perangkutan. Bandung: ITB, 1990.

[7] D. Santosa, "Pengertian, Cara dan Jenis Parkir," Http://Www.Galeripustaka.Com, 2013. [Online]. Available: http://www.galeripustaka.com/2013/05/pengertian-cara-dan-jenisparkir.html. [Accessed: 11-Aug-2019]. 
[8] S. Y. K. Rompas, "Location Based Service (LBS)," 2013 [Online]. Available: https://supeeerblog.blogspot.com/2013/05/location-basedservices-lbs.html. [Accessed: 28-Aug-2019].

[9] V. Yasin, Rekayasa Perangkat Lunak Berorientasi Objek. Jakarta: Mitra Wacana Media, 2012.

[10] R. Sukamto and S. M, Rekayasa Perangkat Lunak Terstruktur dan Berorientasi Objek. Bandung, 2018.

[11] R. Soetam, Konsep Dasar Rekayasa Perangkat Lunak (Software Engeenering). Jakarta, 2011.

[12] W. E. Perry., Effective Methods for Software Testing(second edition), 3rd Editio. Indianapolis: Wiley Publishing, Inc, 2000

[13] J. Enterprise, Pengenalan HTML dan CSS. Jakarta: PT. Elex Media Komputindo, 2016.

[14] Z. A. Rozi and S. Community, Modern Web Design. Jakarta: PT. Elex Media Komputindo, 2016.

[15] J. Enterprise, PHP Komplet. Jakarta: PT. Elex Media Komputindo, 2017.

[16] J. Enterprise, Otodidak MySQL untuk Pemula. Jakarta: PT. Elex Media Komputindo, 2017.

[17] Y. Yudhanto and H. A. Prasetyo, Panduan Mudah Belajar Framework Laravel. Jakarta: PT. Elex Media Komputindo, 2018. 